\title{
Mobile dental clinic revitalization to improve oral health services in the covid-19 pandemic era at Sambirejo District Community Health Center, Kabupaten Langkat
}

\author{
Wandania Farahanny ${ }^{* 1}$, Ika Andryas ${ }^{2}$, Rini Octavia N ${ }^{3}$, Olivia A Hanafiah ${ }^{4}$ \\ ${ }^{1}$ Conservative Dentistry Departments \\ ${ }^{2}$ Prosthodontic Departments \\ ${ }^{3}$ Periodontology Departments \\ ${ }^{4}$ Maksilofasial Surgery Departments \\ Faculty of Dentistry, Universitas Sumatera Utara, Medan Indonesia \\ *Email: wandania@usu.ac.id
}

\begin{abstract}
One of pandemic effect is that people being afraid to have their regular dental treatment and tends to have their own medication. Dentist and dental nurses as workerin public health provider also afraid on doing dental treatment on a reason highly contamination and transmission of the virus. Delaying aerosol generating procedures is found as the only choice, except for emergency case. However, the uncertainty of pandemic era and dental treatment needs, urge the health workers to have innovation in dental treatment service. Using mobile dental clinic Dinas Kesehatan Kabupaten Langkat di Puskesmas Sambirejo is a solution. The implementation of service activities in mobile dental clinic are mainly in self Protection equipment, SOP in Standart Precaution, sterlisation and aseption and also patients admision flow in pandemic era for health care providers as a way to improve their knowledge in handling patient in pandemic era. The delay of action in dental procedur can be solved by facilitating mobile dental clinic according to standard health protocol. Instead of only reaching rural area, this mobile dental clinic can also be used in narrow building with limited space. The SOP protocol can also be used by dentis and dental nurses to control infection in mobile dental clinic. This article tries to support government in raising the degree of mouth and dental health services in pandemic era.
\end{abstract}

Key words: Pandemic, Mobile dental unit

\begin{abstract}
Abstrak
Salah satu dampak pandemi adalah masyarakat takut berobat gigi secara regular dan memilih mengobati diri sendiri. Dokter gigi dan perawat gigi di puskesmas juga merasa khawatir melakukan tindakan prosedur perawatan gigi karena tingginya resiko transmisi dan kontaminasi virus. Penundaan prosedur aerosol generating procedures kecuali kegawatdaruratan merupakan satu satunya pilihan. Namun, lamanya masa pandemi dan kebutuhan perawatan gigi, memaksa praktisi kesehatan untuk berinovasi dalam penyesuaian layanan kedokteran gigi. Pemanfaatan ketersediaan Mobil Poli Klinik Gigi Keliling Dinas Kesehatan Kabupaten Langkat di Puskesmas Sambirejo merupakan suatu solusi. Pelaksanaan kegiatan pengabdian fokus pada persiapan Mobil Poli Klinik Gigi Keliling, khususnya persiapan Alat Pelindung Diri, SOP Standart Precaution, SOP Sterilisasi dan Asepsi serta SOP Alur Penerimaan Pasien di Masa Pandemi bagi para tenaga kesehatan sebagai cara upgrade knowledge penanganan pasien dimasa Pandemi. Penundaaan tindakan dengan aerosol pada prosedur kedokteran gigi dapat diatasi dengan fasilitas pada Mobil Poli Gigi Keliling sesuai standar protokol kesehatan. Selain menjangkau daerah perifer, mobil ini dapat digunakan di gedung dengan ruang terbatas. Panduan protokol SOP dapat digunakan dokter gigi dan perawat gigi dalam pengendalian infeksi di dalam Mobil Poli Gigi Keliling. Tulisan ini bertujuan membantu pemerintah meningkatkan derajat pelayanan kesehatan gigi dan mulut pada masa pandemi COVID-19.
\end{abstract}

Kata kunci: Pandemi, Mobil Poli Gigi Keliling 


\section{PENDAHULUAN}

COVID-19 adalah singkatan dari Corona Virus 2019, merupakan suatu penyakit menular yang disebabkan oleh virus Severe Acute Respiratory Syndrome Coronavirus-2 (SARS-CoV2). Penyakit pernafasan akut ini pertama kali diidentifikasi di kota Wuhan, Tiongkok pada akhir tahun 2019 lalu meluas ke seluruh dunia dalam waktu yang sangat singkat. Pada tanggal 11 Maret 2020, Badan Kesehatan Dunia yaitu WHO secara resmi menyatakan bahwa COVID-19 merupakan kategori pandemi global. Kemudian Indonesia pun menetapkan COVID-19 sebagai bencana nasional pada tanggal 14 Maret 2020. Peningkatan angka kematian disebabkan penyakit COVID-19 mendorong masing masing negara menyikapinya dengan berbagai kebijakan dalam upaya pemutusan rantai penularan.

Saat ini, pada tanggal 26 November 2020 data menunjukkan total kasus positif sebanyak 516.753 kasus, 433.649 kasus sembuh dan 16.352 kasus meninggal. Walaupun angka tersebut menunjukkan jumlah kasus penyakit yang tinggi, akan tetapi bila dibandingkan dengan jumlah populasi penduduk Indonesia yang lebih dari 267 juta jiwa, maka perbandingan jumlah masyarakat yang tidak terinfeksi masih lebih tinggi. Oleh sebab itu upaya pelayanan kesehatan lainnya seperti peningkatan kesehatan (promotif) dan pencegahan penyakit (preventif) untuk masyarakat yang sehat seyogianya tetap menjadi perhatian bagi petugas pelayanan kesehatan terutama di Puskesmas yang menjadi ujung tombak pelayanan kesehatan.

Penyakit gigi dan mulut merupakan salah satu masalah kesehatan masyarakat di Indonesia. Hasil Riset Kesehatan Dasar (RISKESDAS) pada tahun 2019 menyatakan penyakit gigi dan mulut menunjukkan angka prevalensi yang cukup tinggi yaitu sebesar $61 \%$. Dari data tersebut terlihat proporsi terbesar masalah gigi di Indonesia adalah gigi rusak/karies $(45,3 \%)$. Sedangkan masalah kesehatan mulut yang mayoritas dialami penduduk Indonesia adalah gusi bengkak dan/atau adanya infeksi nanah seperti bisul (abses) sebesar 14\%. Tingginya prevalensi masalah penyakit gigi dan mulut ini, dan menjadi salah satu dari sepuluh besar urutan penyakit yang sering dikeluhkan masyarakat di Indonesia.

Puskesmas merupakan salah satu fasilitas kesehatan umum pemerintah tingkat pertama memiliki peran dalam hal prevensi, deteksi, dan respon sesuai dengan kewenangannya. Namun disisi lain puskesmas juga tetap memiliki tanggung jawab untuk menjalankan fungsinya dalam meningkatkan kesehatan masyarakat dan upaya kesehatan perseorangan walaupun masa pandemi ini berlangsung. Kejadian pandemi ini mendorong puskesmas untuk tetap menjalankan pelayanan terkait kasus COVID-19 dan juga ber terintegrasi dengan pelayanan lainnya. Salah satunya adalah tetap melaksanakan standar pelayanan minimal khususnya pelayanan kesehatan gigi dan mulut dengan menyesuaikan kondisi puskesmas dan protokol kesehatan. Sayangnya salah satu dampak kondisi pandemi ini mengakibatkan masyarakat masih takut untuk berobat gigi secara regular ke puskesmas dan memilih untuk mengobati diri sendiri dengan cara mengkonsumsi obat pereda nyeri yang beredar di pasaran. Selain itu dokter gigi dan perawat gigi yang bekerja di puskesmas masih merasa khawatir untuk melakukan tindakan prosedur perawatan gigi karena tergolong dalam resiko tinggi transmisi dan kontaminasi virus SARS-CoV2 dengan fasilitas peralatan gigi yang minim.

Transmisi penularan virus SARS-CoV2 ini dapat terjadi melalui droplet dan kontak langsung terhadap permukaan yang terkontaminasi dengan virus. Media penularan lainnya dapat berasal dari prosedur yang menimbulkan aerosol dari penggunaan alat scaller ultrasonic dan high speed air driven yang sangat beresiko jika masuk ke saluran pernafasan 
dan mengkontaminasi permukaan. Bahkan di beberapa penelitian menemukan virus SARSCoV2 pada air liur pasien tanpa gejala batuk atau gejala gangguan pernafasan. Hal ini yang menyebabkan para dokter gigi dan perawat gigi menunda tindakan ataupun membatasi aktifitas pelayanan kesehatan gigi. Beberapa puskesmas hanya dapat melakukan tindakan premedikasi dan menunda perawatan gigi di masa pandemi ini.

Pada awalnya berbagai organisasi kesehatan gigi internasional maupun nasional mengeluarkan rekomendasi untuk melakukan pelayanan kedokteran gigi yang aman selama masa pandemi. Salah satunya menunda seluruh prosedur yang bersifat menimbulkan aerosol generating procedures kecuali termasuk dalam keadaan kegawatdaruratan. Namun seiring dengan perjalanan waktu dan kebutuhan akan berbagai perawatan gigi, maka diperlukan suatu bentuk penyesuaian untuk dapat beradaptasi pada pelayanan prosedur kedokteran gigi. Persatuan Dokter Gigi Indonesia (PDGI) sudah menetapkan pedoman pelayanan kedokteran gigi selama pandemi COVID-19 sebagai panduan dasar kepada dokter gigi dalam melakukan praktek kedokteran gigi. Selain itu Kementerian Kesehatan Republik Indonesia juga mengeluarkan buku petunjuk teknis sebagai acuan bagi seluruh petugas Puskesmas dalam melaksanakan tugas dan fungsinya pada situasi pandemi COVID-19.

Kenyataannya kondisi di lapangan sering sekali tidak dapat dilakukan sesuai dengan pedoman dan panduan yang sudah ditetapkan. Penerapan alur pelayanan dengan prinsip skrining/triase dan menjaga jarak (physical distancing) masih sulit untuk diterapkan apabila fasilitas fisik/gedung puskesmas yang masih minim dan terbatas. Ketersediaan alat pelindung diri (APD) dan peralatan precaution standar yang masih terbatas, lokasi puskesmas utama yang terletak jauh dari desa, jumlah tenaga kesehatan dokter gigi atau perawat gigi yang minim, dan kurangnya pengetahuan terkini mengenai pengendalian infeksi di masa pandemi COVID-19 merupakan masalah yang ditemui pada daerah pedesaan ataupun tingkat kabupaten.

Salah satu permasalahan ini juga dijumpai ketika akan melanjutkan upaya peningkatan kesehatan gigi dan mulut di Desa Suka Makmur, Kecamatan Binjai, Kabupaten Langkat. Desa ini hanya memiliki puskesmas pembantu yang tidak ada pelayanan kesehatan gigi dan dokter gigi. Desa Suka Makmur ini merupakan tempat program Desa Binaan kerjasama dengan Lembaga Pengabdian Pada Masyarakat (LPPM) Universitas Sumatera Utara pada tahun 2019 yang merupakan salah satu implementasi Tridarma Perguruan Tinggi. Dosen mempunyai tanggung jawab dalam pengabdian masyarakat dan ikut perperan dalam menurunkan angka penyakit gigi dan mulut. Program pengabdian ini, menjadi salah satu upaya monitoring dan evaluasi serta upaya kuratif bagi masyarakat setempat yang masih memiliki insiden permasalahan gigi dan mulut yang cukup tinggi. Tingginya penyakit gigi pada masyarakat Desa Suka Makmur tidak mendorong masyarakat untuk segera mencari pengobatan ke dokter gigi atau datang ke Puskesmas utama yaitu di Puskesmas Sambirejo. Hal ini mungkin disebabkan letak Puskesmas Sambirejo yang jauh dari desa Suka Makmur, masih kurangnya pemahaman masyarakat mengenai pentingnya kesehatan gigi dan mulut dalam meningkatkan kualitas hidup. Selain itu kondisi pandemi ini juga menjadi alasan yang membuat masyarakat masih takut dan membatasi untuk bepergian jauh.

Namun ketersediaan Mobil Poli Klinik Gigi Keliling Dinas Kesehatan Kabupaten Langkat yang saat ini dikelola Puskesmas Sambirejo dapat memberikan kekuatan tersendiri dan menjadi langkah besar dalam upaya pelayanan kesehatan gigi dan mulut masyarakat setempat. Selama ini penggunaan dental unit yang berada di dalam mobil poli klinik gigi tersebut masih belum maksimal. Oleh sebab itu, program Revitalisasi Mobil Poli Gigi Keliling sebagai sarana pelayanan kesehatan gigi dan mulut diharapkan dapat menjadi salah satu solusi pemecahan masalah bagi masyarakat yang memiliki kesulitan akses untuk 
mencapai fasilitas pelayanan kesehatan utama. Selain itu Mobil Poli Klinik Gigi sangat sesuai digunakan di masa pandemi COVID-19 karena dapat diletakkan di area lingkungan puskesmas untuk tetap menjaga alur pelayanan dengan prinsip skrining/triase dan menjaga jarak (physical distancing), dan melindungi kemungkinan kontaminasi karena berada di tempat yang terpisah dari gedung puskesmas.

Kegiatan revitalisasi yang dilakukan meliputi sterilisasi, desinfeksi dan Maintenance action pada Dental Chair dan alat alat didalamnya agar dapat digunakan dengan maksimal oleh Dokter Gigi Puskesmas Sambirejo khususnya melayani pasien di masa pandemi Covid-19. Panduan tehnis penggunaan kegiatan pelayanan tindakan dokter gigi sesuai standard prosedur pada Mobil Poli Klinik Gigi Keliling di masa pandemi Covid-19 telah direkam dalam bentuk video edukasi yang dapat dimanfaatkan oleh seluruh Dokter Gigi Puskesmas yang akan bertugas menggunakan fasilitas Mobil tersebut. Selain itu dilakukan juga pengaturan ventilasi ruang kerja sebagai kontrol infeksi untuk keselamatan kerja dokter gigi dan perawatan gigi yang akan bekerja di dalam mobil tersebut

Tujuan dari pelaksanaan kegiatan ini adalah untuk membantu upaya pemerintah meningkatkan derajat kesehatan khususnya pelayanan kesehatan gigi dan mulut pada masyarakat desa yang tidak memiliki sarana pelayanan kesehatan yang memadai dengan cara pemanfaatan kembali dan revitalisasi mobil poli klinik gigi sehingga dapat menjangkau desa area terpencil. Selain itu pemberdayaan kembali penggunaan fasilitas dental unit di mobil poli gigi di lingkungan puskesmas Sambirejo dapat meningkatkan pelayanan kesehatan gigi dan mulut di masa pandemi COVID-19 dan menjaga keselamatan kerja.

\section{METODE PELAKSANAAN}

Metode yang dilakukan oleh Tim dalam kegiatan pengabdian masyarakat ini yaitu membantu memberdayakan kembali fungsi dari Mobil Poli Klinik Gigi Keliling agar dapat dimanfaatkan untuk lebih maksimal dalam memberikan pelayanan kesehatan gigi dan mulut di masa pandemi COVID-19. Revitalisasi mobil ini diharapkan dapat membantu upaya puskesmas menjalankan fungsinya sebagai garda terdepan memberikan pelayanan kesehatan kepada masyarakat, khususnya pelayanan kesehatan gigi dan mulut. Tahapan pelaksanaan kegiatan pengabdian ini adalah sebagai berikut.

1. Survei Lokasi dan Kondisi Mobil Poli Klinik Gigi Keliling.

Bertujuan untuk melihat lokasi dan fasilitas pada Desa Suka Makmur yang merupakan Desa Binaan. Selain itu dilakukan survei ketersediaan fasilitas pelayanan gigi dan data pasien gigi di Puskesmas Sambirejo. Kemudian tim juga melakukan survei kondisi awal Dental Unit pada Mobil Poli Klinik Gigi Keliling yang dapat dilihat pada Gambar 1.

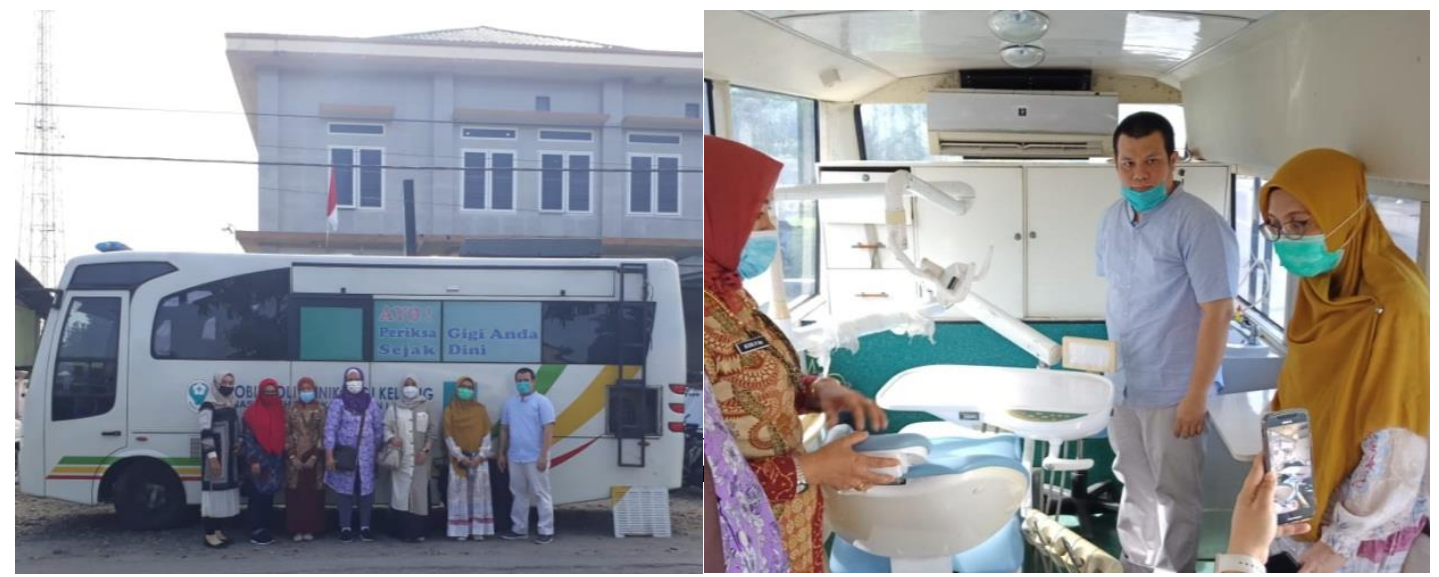


Komunikasi efektif dengan jajaran pimpinan Kepala Dinas Kabupaten Langkat dan Kepala Puskesmas Sambirejo juga dilakukan untuk mendapatkan legalitas izin untuk melakukan revitalisasi Mobil Poli Klinik Gigi ini.

2. Tahap Pemeriksaan Spesifik dan Analisis Kelayakan.

Pemeriksaan kondisi Dental Unit dan peralatan kedokteran gigi yang ada pada Mobil Poli Klinik Gigi dilakukan oleh tenaga ahli yaitu tehnisi dental. Selain itu juga dilakukan pemeriksaan kondisi alat penunjang lainnya seperti wastafel, kursi ruang

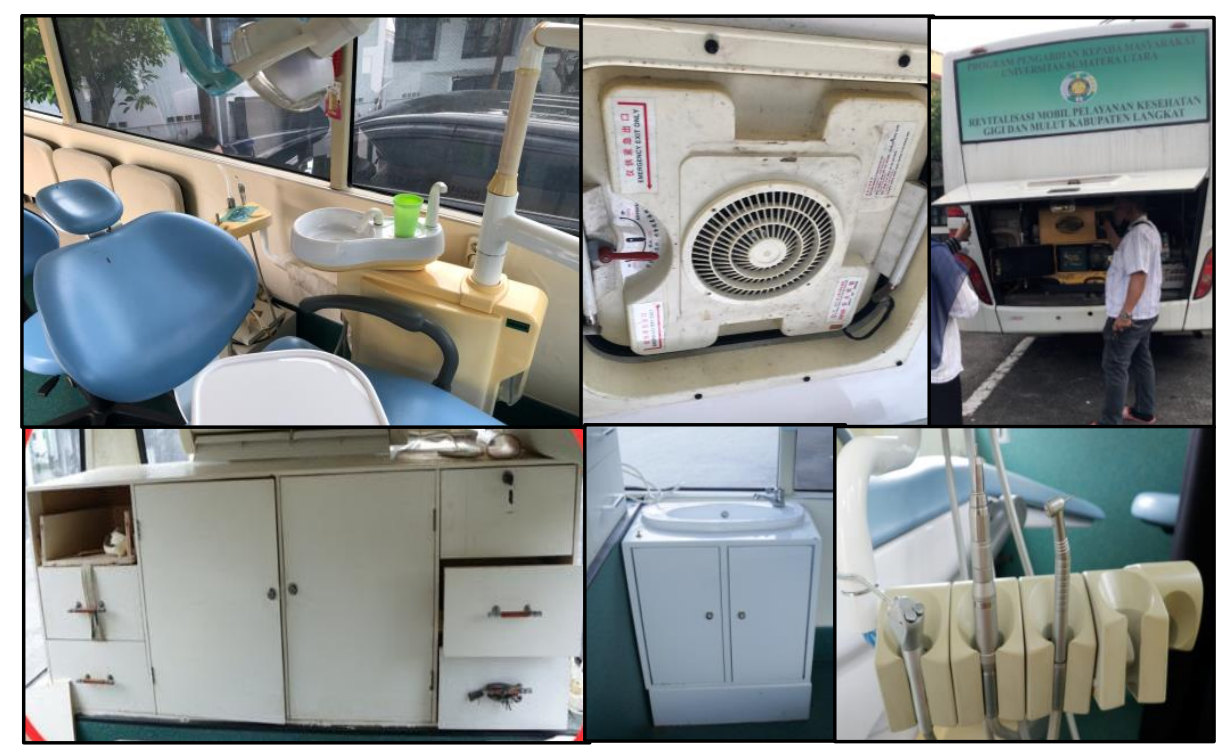

Gambar 2. Pemeriksaan kondisi Dental Unit dan alat penunjang lainnya seperti mesin diesel, kompresor, ventilator, lemari penyimpan alat, wastafel, dan high speed air driven bur.

tunggu built in, lemari penyimpan alat, tabung kompresor, ventilasi, mesin diesel dan pendingin ruangan (AC). Kemudian dilakukan analisis kelayakan dari semua alat penunjang tersebut untuk merencanakan tindakan perbaikan, penggantian atau pemeliharaan alat (Gambar 2).

3. Studi pustaka

Bertujuan untuk menyusun suatu panduan tehnis dan alur prosedur standar pasien untuk melakukan tindakan pelayanan kedokteran gigi pada Mobil Poli Klinik Gigi yang disesuaikan dengan protokol kesehatan COVID-19.

4. Persiapan alat dan bahan yang dibutuhkan

Bertujuan untuk mempersiapkan bahan dan peralatan kedokteran gigi yang diperlukan sesuai standar protokol kesehatan COVID-19. Disediakan juga alat pelindung diri (APD) level 2 dan level 3 untuk dokter gigi dan perawat gigi yang nantinya akan bekerja di dalam Mobil Poli Klinik Gigi (Gambar 3).

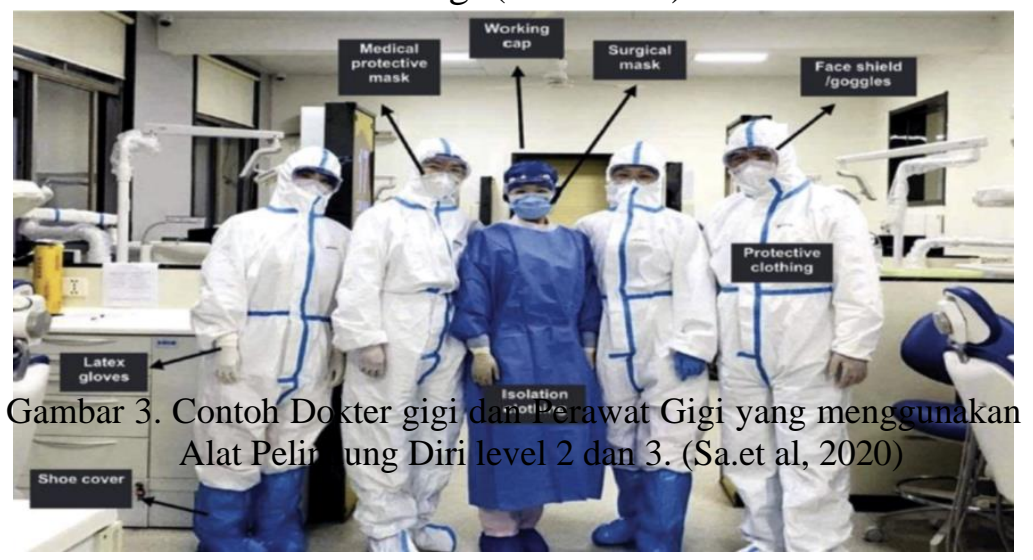


5. Revitalisasi Mobil Poli Klinik Gigi.

Kegiatan revitalisasi yang dilakukan meliputi sterilisasi, desinfeksi dan Maintenance action pada Dental Chair dan alat-alat didalamnya agar dapat digunakan dengan maksimal oleh Dokter Gigi Puskesmas Sambirejo khususnya melayani pasien di masa pandemi Covid-19 yang dapat dilihat pada Gambar 4. Panduan tehnis penggunaan kegiatan pelayanan tindakan dokter gigi sesuai standard prosedur pada Mobil Poli Klinik Gigi Keliling di masa pandemi Covid-19 telah direkam dalam bentuk video edukasi yang dapat dimanfaatkan oleh seluruh Dokter Gigi Puskesmas yang akan bertugas menggunakan fasilitas Mobil tersebut. Selain itu dilakukan juga pengaturan ventilasi ruang kerja sebagai kontrol infeksi untuk keselamatan kerja dokter gigi dan perawatan gigi yang akan bekerja di dalam mobil tersebut.

6. Pelatihan kader puskesmas

Terkait dengan kondidi pandemi COVID-19, memaksa Tim untuk melaksanakan

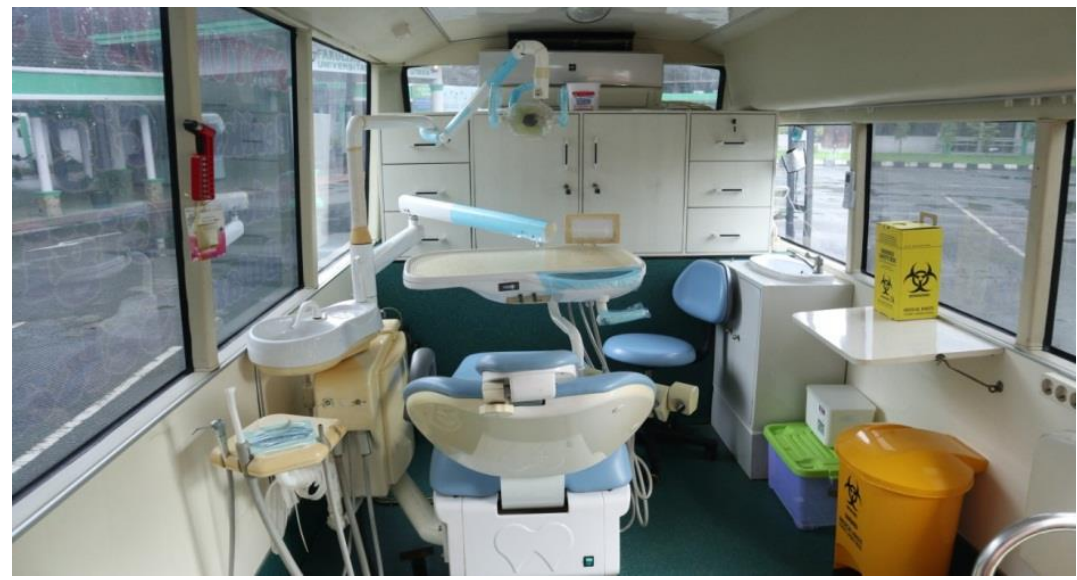

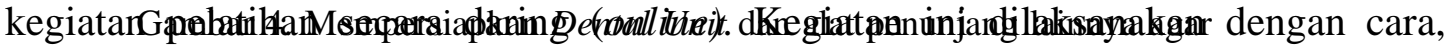

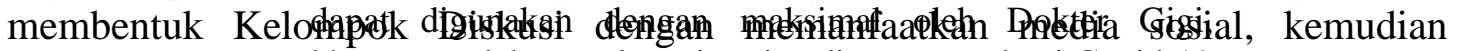

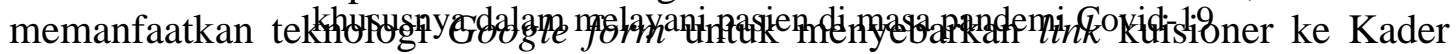
kesehatan puskesmas yang dapat dilihat pada Gambar 5. Interaktif Kelompok Diskusi terlihat dari aktifnya peserta kader yang melakukan tanya jawab di dalam media online tersebut. Selain itu Tim juga membuat suatu video Pembelajaran mengenai edukasi teknik penyikatan gigi yang dapat di manfaatkan untuk membantu kader kesehatan puskesmas dalam mengedukasi masyarakat desa.

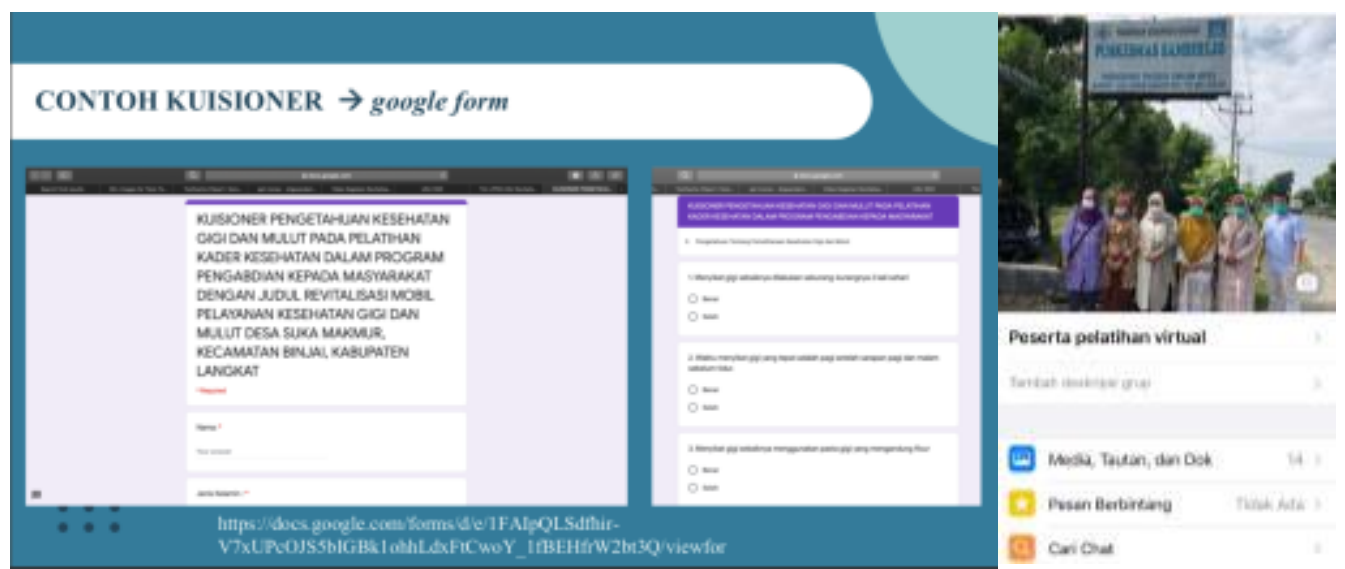

Gambar 5. Membentuk Kelompok Diskusi dengan memanfaatkan media sosial, kemudian memanfaatkan teknologi Google form untuk menyebarkan link kuisioner ke Kader kesehatan puskesmas 
7. Menyusun rencana kerja sama berkesinambungan.

Bertujuan agar rencana kerjasama dalam meningkatkan derajat kesehatan gigi dan mulut antara Lembaga Pengabdian Masyarakat Universitas Sumatera Utara dengan Kabupaten Langkat terus dapat dilaksanakan secara bertahap dan berkesinambungan.

\section{HASIL DAN PEMBAHASAN}

Langkah awal program revitalisasi Mobil Poli Klinik Gigi Keliling ini dimulai dengan membawa mobil tersebut ke Fakultas Kedokteran Gigi USU pada bulan July 2020. Sebelum melakukan persiapan untuk revitalisasi Mobil Poli Klinik Gigi Keliling, terlebih dahulu Tim melakukan studi literatur mengenai persiapan ruang poli gigi pada masa pandemi COVID-19. Pelayanan Medik dilaksanakan sesuai dengan Standar Prosedur Operasional (SOP) pelayanan yang berlaku. Alur penerimaan pasien yang akan di rawat di dalam Mobil Poli Klinik Gigi Keliling dibuat untuk mencegah penularan COVID-19 dengan cara menerapkan prinsip triase/ skrining. Pasien tetap menunggu di luar agar prinsip physical distancing tetap di jaga, karena ruang kerja dokter gigi di dalam Mobil terbatas.

Setiap pasien yang datang harus di ukur suhu badannya terlebih dahulu dan mengisi formulir untuk memberikan informasi data awal keluhan pasien dan memastikan pasien yang akan masuk ke ruang poli gigi tidak suspek terinfeksi virus SARS-CoV2. Informasi ini dapat disampaikan secara tertulis menggunakan tulis cetak atau pemanfaatkan media teknologi online. Tehnologi pendaftaran secara daring juga dapat dimanfaatkan sebagai bentuk pembatasan pasien menunggu diruang pelayanan. Penggunaan teledentistry dalam bentuk konsultasi menggunakan tehnologi online dapat diajurkan untuk mengurangi resiko kontak antara masyarakat/pasien dengan petugas kesehatan di puskesmas. Apabila pada saat skrining ini ditemui pasien yang diduga terinfeksi virus SARS-CoV2 maka segera dirujuk ke Fasilitas Kesehatan Rujukan Tingkat Lanjut terdekat, untuk menghindari terjadi penularan lebih jauh.

Hasil laporan bulanan program gigi dan mulut UPT Puskesmas Sambirejo menunjukkan kunjungan pasien yang menurun selama masa pandemi. Tindakan yang dapat dilakukan pada pasien hanya sebatas pemberian premedikasi terhadap penyakit gigi tanpa tindakan kedokteran gigi. Hal ini disebabkan terbatasnya fasilitas untuk melakukan kontrol infeksi di ruang poli gigi Puskesmas Sambirejo untuk tindakan yang memicu terjadinya aerosol. Sebuah studi penelitian melaporkan bahwa aerosol dengan partikel berukuran 0,5 hingga $10 \mu \mathrm{m}$ dapat dapat mengambang di udara di jarak 1-1,5 $\mathrm{m}$ dan memungkinkan untuk tertular apabila masuk melalui saluran nafas. Jika dipertimbangkan dari jenis profesi, memang dokter gigi termasuk yang beresiko tinggi terpapar aerosol. Prosedur kedokteran gigi seperti penggunaan handpiece berkecepatan tinggi, semprotan air yang digerakkan oleh tekanan udara dan scaler ultrasonic dapat menimbulkan aerosol yang berisi bahan biologis seperti air ludah, darah, struktur gigi dan plak gigi. Oleh sebab itu dokter gigi dan perawat gigi yang bekerja di masa pandemi ini harus selalu menggunakan Alat Pelindung Diri (APD).

Penetapan penggunaan Alat Pelindung Diri (APD) mengikuti beberapa unsur yang harus dipatuhi seperti, pemilihan jenis APD yang tepat, cara memakai dengan benar, cara melepaskan dengan benar dan cara mengumpulkan (disposal) setelah dipakai. Ketersedian Mobil Poli Klinik Gigi Keliling ini dapat menjamin prosedur pelayanan gigi dan mulut darurat, dimana penggunaan scaler ultrasonic dan high speed air driven bur tetap dapat dilakukan dengan menggunakan Alat Pelindung Diri (APD) yang tepat. Dokter Gigi dan Perawat gigi selama bekerja di mobil Poli Klinik Gigi Keliling ini dianjurkan menggunakan Alat Pelindung Diri level 3 sesuai dengan Standar Prosedur Operasional (SOP) berupa :

\section{Masker N 95}


2. Gaun coverall dengan zipper

3. Sarung Tangan

4. Pelindung Wajah (Face Shield) atau Kacamata pelindung (Google)

5. Pelindung Kepala atau nurse cap

6. Sepatu pelindung atau Boots

Kontrol ruangan instalasi juga menjadi bagian terpenting dalam pengendalian infeksi menyeluruh. Penggunaan alat pendingin ruangan (air conditioner) perlu memperhatikan arah angin yang dikeluarkan agar mengarah dari dokter gigi ke arah pasien dan menuju area yang dipasangkan exhaustvan/ventilator/ lubang udara sehingga membantu mengeluarkan udara. Posisi dental chair untuk pasien dan tempat duduk operator/dokter gigi pada mobil Poli Klinik Gigi Keliling ini sudah tepat dengan pengaturan letak alat pendingin ruangan yang menuju ke arah lokasi tempat ventilator electric yang sudah ada pada atap mobil.

Prosedur desinfeksi dan sterilisasi harus tetap menjadi perhatian tenaga kesehatan yang akan bekerja menggunakan Mobil Poli Klinik Gigi Keliling. Pembersihan ruangan dan alat dilakukan setiap setelah pemeriksaan pasien selesai. Desinfeksi pada seluruh permukaan kontak harus dibersihkan dengan cairan intermediate or low level disinfectant seperti alkohol $70-90 \%$, sodium hipoklorit 5,25\%, detergen fenolik atau detergen iodofor. Dianjurkan untuk selalu melapisi kembali permukaan kontak dengan bahan pelapis (plastic wrap) setiap pertukaran pasien. Hal ini bertujuan untuk memastikan setiap tahap pekerjaan tidak terjadi kontaminasi infeksi silang dari pasien ke petugas medis yaitu dokter gigi dan perawat gigi yang melakukan tindakan pelayanan kedokteran gigi dan mulut.

Penggunaan obat kumur antiseptik sebelum dilakukan tindakan prosedur pemeriksaan gigi dan mulut pada setiap pasien adalah merupakan salah satu upaya untuk mencegah penyebaran virus SARS-CoV2. Penelitian sudah menunjukkan obat kumur yang mengandung Povidone- Iodine 1\% terbukti dapat mengurangi virus secara in vitro sebanyak $99,9 \%$ dalam waktu 30 detik. Penggunaan obat kumur yang mengandung hydrogen peroksida $0,5 \%-1 \%$ selama 1 menit juga terbukti efektif terhadap virus SARS-CoV2.

Pelaksanaan kegiatan pengabdian ini memfokuskan untuk persiapan kelengkapan di dalam Mobil Poli Klinik Gigi Keliling seperti service untuk Dental Chair, penyediaan alat dan bahan secara maksimal, khususnya persiapan Alat Pelindung Diri (APD) yang lebih lengkap agar siap digunakan untuk melakukan tindakan pelayanan kasus-kasus darurat yang menjadi rujukan puskesmas di masa Pandemi. Tim juga membuat video sinematografi bekerja sama dengan mahasiswa kedokteran gigi dalam bentuk panduan Standar Prosedur Operasional yang pengambilannya dilakukan di dalam Mobil Poli Klinik Gigi Keliling. Judul video ini adalah: 1) SOP Standart Precaution di Masa Pandemi Covid-19 pada Mobil Poli Klinik Gigi Keliling, 2) SOP Sterilisasi dan Asepsi dan, 3) SOP Alur Penerimaan Pasien di Masa Pandemi Covid-19 pada Mobil Poli Klinik Gigi Keliling. Video ini sudah disosialisakan kepada Kepala Puskesmas Sambirejo sebagai mitra pengabdian dan Dokter Gigi/Perawat gigi di Puskesmas sebagai salah satu cara upgrade knowledge penanganan pasien dimasa Pandemi Covid-19. Selain itu ketiga video ini juga dapat di unduh melalui media online youtube dengan link URL https://www.youtube.com/watch?v=bcKpcyE7mmg, https://www.youtube.com/watch?v=GaJXkN2St9odan,https://www.youtube.com/watch?v=h AhjiLAkw6s

Bagi para praktisi kesehatan dan kader kesehatan yang telah dibentuk di Desa Sambirejo, telah dipersiapkan Video Pembelajaran mengenai edukasi teknik penyikatan gigi yang dapat di manfaatkan untuk mengedukasi masyarakat mengenai pentingnya kesehatan gigi dan mulut bagi masyarakat setempat. Video tersebut diharapkan dapat dipergunakan oleh kader kesehatan sebagai media pengajaran yang sudah sesuai dengan standar aturan yang 
berlaku sehingga kader kesehatan dapat dalam menjalankan fungsinya sebagai promotor kesehatan gigi dan mulut. Seluruh video sinematografi ini sudah dapat di unduh pada media Youtube untuk memudahkan proses pembelajaran.

Saat ini dokter gigi Puskesmas Sambirejo sudah mulai menggunakan fasilitas Mobil Poli Klinik Gigi Keliling untuk pemeriksaan penjaringan masyarakat desa. Dokter gigi sudah dapat menggunakan APD yang diberikan agar upaya kesehatan perorangan tetap berjalan, yang terlihat pada gambar 6 .

\section{KESIMPULAN DAN SARAN}

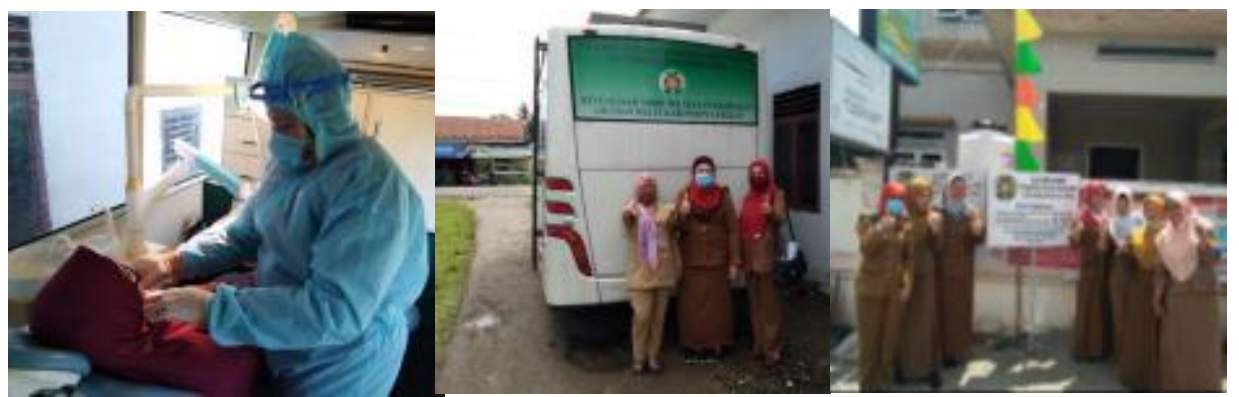

Gambar 6 . Dokter Gigi puskesmas sedang melakukan pemeriksaan gigi dan mulut untuk proses penjaringan pada masyarakat

Pelaksanaan pengabdian masyarakat dengan pemanfaatan kembali mobil dental unit melalui program Revitalisasi Mobil Poli Gigi Keliling Dinas Kesehatan Kabupaten Langkat menjadi solusi untuk mengatasi masalah tertundanya tindakan pelayanan kesehatan gigi dan mulut di masa Pandemi Covid-19. Melalui program ini diharapkan dapat meningkatkan upaya pelayanan kesehatan gigi dan mulut Puskesmas Sambirejo Kabupaten Langkat di masa Pandemi Covid-19. Masyarakat yang sebelumnya tidak dapat dilakukan tindakan prosedur kedokteran gigi yang mengeluarkan aerosol, saat ini dengan adanya fasilitas pada Mobil Poli Gigi Keliling sudah dapat dilakukan dengan tetap mengikuti standar protokol kesehatan.

Selain mobil pelayanan ini dapat menjangkau daerah perifer, mobil ini juga dapat digunakan di area lingkungan fasilitas pelayanan kesehatan, terutama yang memiliki gedung dengan ruang terbatas untuk mengatur alur pelayanan medik. Video sinematografi dalam bentuk panduan mengenai protokol Standar Prosedur Operasional yang dibuat dalam kegiatan ini dapat digunakan untuk tenaga kesehatan gigi yaitu dokter gigi dan perawat gigi dalam meningkatkan keamanan kerja dan pengendalian infeksi selama bekerja di dalam Mobil Poli Gigi Keliling.

Melalui program revitalisasi Mobil Poli Gigi Keliling ini diharapkan dapat menjamin dan meningkatkan kualitas hidup masyarakat dengan salah satunya meningkatkan kesehatan khususnya kesehatan gigi dan mulut pada masyarakat Kabupaten Langkat. Kegiatan ini diharapkan akan dapat dilaksanakan secara bertahap dan berkesinambungan.

Mengingat perkembangan ilmu pengetahuan dan bukti-bukti terbaru terkait pandemi Covid-19 kebijakan atau pedoman yang telah ada akan disesuaikan dengan hal tersebut, maka Puskesmas dan Dinas Kesehatan diharapkan selalu aktif mengikuti perkembangan perubahan ini dari sumber resmi yaitu salah satunya bekerjasama dengan tridarma perguruan tinggi.

\section{UCAPAN TERIMA KASIH}

Artikel ini merupakan salah satu hasil dari Program Pengabdian kepada Masyarakat yang dibiayai oleh Lembaga Pengabdian Kepada Masyarakat Universitas Sumatera Utara tahun 2020 Skema Mono Tahun Reguler Sumber Dana Non PNPB. Oleh karena itu, 
diucapkan terima kasih kepada Rektor dan Ketua LPPM Universitas Sumatera Utara atas dukungan dana dan fasilitas yang diberikan.

\section{DAFTAR PUSTAKA}

Ayub, K., \& Alani, S. (2020). Acute endodontic and dental trauma provision during the Covid-19 crisis. British Dental Journal, 229(3),169-175.

Bhanushali, P., Katge, F., Deshpande, S., Chimata, V. K., Shetty, S., \& Pradhan, D. (2020). Covid-19:changing trendsandits impactonfuture of dentistry. International Journal of Dentistry, 1-6.

Community Health Center, Inc. (2013, Agustus). Adding restorative care to health center mobile dental programs. NNOAH. https://www.nnoha.org/nnohacontent/uploads/2013/08/Adding-Restorative-Care-to-Health-Center-Mobile-DentalPrograms.pdf

Darmawan, I. R., \& Thabrany, H. Refelksi dan impelementasi jaminan kesehatan nasional pada pelayanan kedokteran gigi di fasilitas kesehatan tingkat pertama Kota Tangerang tahun 2017. (2017). Jurnal Kebijakan Kesehatan Indonesia, 6(3), 174-183.

Direktorat Pelayanan Kesehatan Primer \& Direktorat Jenderal Pelayanan Kesehatan Kementerian Kesehatan. (2020). Petunjuk teknis pelayanan puskesmas pada masa pandemi covid-19. Jakarta: Kementerian Kesehatan RI.

Gaffar, B., Alhumaid, J., Alhareky, M., Alonaizan, F., \& Almas, K. Dental facilities during the new corona outbreak: a swot analysis. Risk Management and Healthcare Policy, 13, $1343-1352$.

Lubis, M. L. P., \& Rahman, F.U.A. (2020). Adaptasi era kenormalan baru di bidang radiologi kedokteran gigi: apa yang perlu kita ketahui. Jurnal Radiologi Dentomaksilofasial Indonesia, 4(2), 55-60.

Mair, A. D., \& Korne, P. H. (2020, Mei 21). Decoding dental aerosols. Secibonline. https://secibonline.com/wp-content/uploads/2020/05/Decoding-Dental-Aerosols_May212020.pdf

Mishra, K., Hegde, D., Shetty, S., Shah, S., Priya, A., \& Reddy, S. L. (2020). Coronavirus disease 19 (covid-19) and prosthodontic consideration - a review. Journal of Advanced Medical and Dental Sciences Research, 8(5), 86-92.

O_ner, D., De Grado, G. F., Strub, M., Belotti, L., Deboscker, S., \& Musset, A. M. (2020). Mobile dental delivery system: an e_ective protocol for hygiene and disinfection. International Journal of Environmental Research and Public Health, 17, 1-11. 
Organization for Safety and Asepsis Procedures. (2010). Infection control checklist for dental settings using mobile vans or portable dental equipment. OSAP. https://cdn.ymaws.com/www.osap.org/resource/resmgr/Checklists/OSAP.checklist.port abledenta.pdf

Persatuan Dokter Gigi Indonesia. (2020, Maret 20). Pedoman pelayanan kedokteran gigi selama pandemi virus covid-19. PDGI. http://pdgi.or.id/artikel/pedoman-pelayanankedokteran-gigi-selama-pandemi-virus-covid-19

Rasuna, S. W. G., Palupi, R., Juniady, A., Hapsari, Y., Ilmi, M. N., Murni, N. W., Putri N.S \& Fitriana, A. (2020). Pedoman perlindungan petugas pelayanan kesehatan gigi \& mulut dalam menghadapi penyandang diabetes melitus di masa pandemi covid-19. Surabaya: Departemen IKGM FKG Universitas Airlangga.

Sa, Y., Lin, W. S., Morton, D., \& Huang, C. (2020). Coronavirus disease 2019 (covid-19): experiences and protocols from the department of prosthodontics at the Wuhan University. Journal of Prosthetic Dentistry,1-10.

Sekhsaria, S., Sharma, A, Tiwari, B., Sharma, A., \& Mahajan, T. (2020). Changing paradigm in prosthodontics practice post covid-19 outbreak. IP Annals of Prosthodontics and Restorative Dentistry , 6(2), 1-6.

Singh, S., Rana, A., Jain, V., Sybil, D., \& Khatter, H. (2020). Effect of covid-19 lockdown on dental care of patients: a survey analysis. International Journal of Research and Review, 7(11) 1-7.

Wiener, R. C., Summerlin, T., Smith, L. B., Carrier, D. T., \& Wiener, M. A. (2020). Dental care needs of male versus female children visiting a school-based mobile dental facility in West Virginia. The Journal of Dental Hygiene, 94(3), 48-55. 